\title{
Canal irrigation water regimes for Food Production in the Eastern Uttar Pradesh (India)
}

\author{
Raj Mani and R.B. Gautam* \\ N.D. University of Agriculture and Technology, Faizabad (UP) \\ *Email: rksh_gautam@yahoo.co.in
}

\begin{abstract}
Water resources have been recognized as a limiting factor in development of most of the semi arid regions. Optimal utilization of available surface water resources, in canal command areas would result better utilization by maximizing the net benefits from the food production. The feasibility of water management can be analyzed by using a mathematical model. The study was undertaken in the Sharda sahayak canal command area of Sultanpur district of Uttar Pradesh-India. The water demand and available water resources in the study area has been evaluated considering surface water resources. This paper presents a simple economic- engineering optimization model to explore the possibilities of surface water irrigation using linear programming, and to arrive at an optimal cropping pattern for optimal utilization of water to maximizing net food production. The LINDO 6.1, optimization package has been used in arriving at optimal allocation plan of surface water resources. Three cases have been formulated considered different percentage of area under the different crops in the Rabi season. In the first case the net benefit of $200 \%$, more was found as compared to the present condition. A net benefit of $99480.54 \mathrm{M}$ Rs. has been obtained along with 4981 ha m utilization of surface water for irrigation. A net benefit of $99514.55 \mathrm{M}$ Rs has been obtained by using 4981 ha $\mathrm{m}$ of surface water in the second case. While in the third case the net benefit of 99466.96 M Rs. has been obtained by using 4981 ha m surface water for irrigation in the study area. The results indicate that surface irrigation water use options are feasible and can be easily implemented in the study area under planned way.
\end{abstract}

Keywords: Conjunctive use, cropping pattern, LINDO, Surface water, Groundwater, Linear programming.

Paper cited: Rajmani and Gautam, R.B. (2016). Canal irrigation water regimes for Food Production in the Eastern Uttar Pradesh (India). South Asian Journal of Food Technology and Environment, 2(2): 372380.

\section{Introduction}

Increase in water demand poses new challenges for water resource planners to keep pace with the increase in population. Agricultural production needs to be increased which is possible through development of new water resources projects or efficient water management within the existing projects. Considering the above -mentioned aspects an attempt has been made to study the surface water use planning for increasing crop production in Kurebhar block of Sultanpur district lies under Sharda-sahayak command network of Uttar Pradesh, India. The Kurebhar block which is entirely canal irrigated block by the Sharda-sahayak canal command area of
Sultanpur district (lying between 81 32 '$82^{\circ} 41^{\prime}$ 'east longitude and $25^{\circ} 59^{\prime}-26^{\circ} 40$ 'north latitude) of eastern Uttar Pradesh in north India. The area is a part of the agriculturally important Indo-Gangetic plain with an area of $4436 \mathrm{sq} \mathrm{km}$ and home to more than 2.59 million people with a population density of 583 . The climate is monsoon type and is characterized by hot summer and cold winter season. The average annual rainfall is about $1000 \mathrm{~mm}$. About $90 \%$ of annual rainfall is received during the months of June to September.

Several modeling approaches, such as linear programming, dynamic programming, etc are studied by Aron, (1969); Aron and Scott, (1971); Haimes and Dreizen, (1977); O’Mara 
and Duloy, (1984); Illangasekare et al., (1984); Willis et al., (1989); Onta et al., (1991); Matsukawa et al., (1992); Reichard, (1995); Watkins and Mc Kinney, (1998); Azaiez and Hariga, (2001); Rao, et al., (2004); Karamouz et al., (2004); Syaukt and Fox, (2004); Vedula et al., (2005) .Latif and James (1991) presented a linear programming to maximize the net food production. Hence the primary objective of the present study is to evaluate the feasibility of the surface irrigation water use, and to arrive at an optimal cropping pattern for maximization of net food production under various physical and economic constraints. This paper initially discusses briefly the characteristics and current use of water resources in the Sharda-sahayak canal command area, leading to identification of relevant economic issues in their use. The
LINDO 6.1 optimization package has been used to solve the linear optimization model.

\section{Materials and methods}

The kurebhar block has rich network of main canal, its distributaries and minors. Sufficient numbers of outlets from these networks gives the discharges of irrigation water which is calculated and tabulated. The study block has the salinity due to the development of sodicity and water logging by extensive canal system network and poor water management. Allocation and availability of canal water for irrigation in the study area has shown in Table 1. It has also observed under dry periods of canal irrigation system the farmers are also dependent of their shallow tube wells owned by themselves for safer side. Since this water is costlier, hence their use is negligible in the study area.

Table 1: Allocation and availability of canal water in the study area.

\begin{tabular}{|c|c|c|c|c|c|}
\hline S. No. & $\begin{array}{c}\text { Period } \\
\text { (month) }\end{array}$ & $\begin{array}{l}\text { Discharge } \\
\text { (cum/sec) }\end{array}$ & $\begin{array}{c}\begin{array}{c}\text { Volume of } \\
\text { water allocated } \\
\text { (ha-m) }\end{array} \\
\end{array}$ & $\begin{array}{c}\text { Seepage loss } \\
\text { from the } \\
\text { main canal (ha-m) }\end{array}$ & $\begin{array}{l}\text { Volume of water } \\
\text { available (ha-m) }\end{array}$ \\
\hline 1 & July & 1.000 & 267.84 & 53.57 & 214.27 \\
\hline 2 & Aug & 0.700 & 187.49 & 37.50 & 149.99 \\
\hline 3 & Sept & 0.700 & 181.44 & 36.29 & 145.15 \\
\hline 4 & Oct & 0.700 & 187.49 & 37.50 & 149.99 \\
\hline 5 & Nov & 3.950 & 1023.84 & 204.77 & 819.07 \\
\hline 6 & Dec & 3.950 & 1057.97 & 211.59 & 846.37 \\
\hline 7 & Jan & 3.950 & 1057.97 & 211.59 & 846.37 \\
\hline 8 & Feb & 1.950 & 471.74 & 94.35 & 377.40 \\
\hline 9 & Mar & 1.950 & 505.44 & 101.09 & 404.35 \\
\hline 10 & April & 1.950 & 522.29 & 104.46 & 417.83 \\
\hline 11 & May & 1.950 & 505.44 & 101.09 & 404.35 \\
\hline 12 & June & 1.000 & 259.20 & 51.84 & 207.36 \\
\hline \multicolumn{6}{|c|}{ Total allocation during the year (average) } \\
\hline \multicolumn{6}{|c|}{ Total losses in main canal } \\
\hline \multicolumn{6}{|c|}{ Water available at outlet head } \\
\hline
\end{tabular}

There are three main cropping seasons in the area that include a Kharif season from June to September, Rabi season from October to February and Zaid season from March to May. Major crops during the rainy season are paddy (rice), sugarcane and maize and during the Rabi season wheat, pulses and oilseeds are the main crops. During the Zaid season urd bean, mungbean and maize are main crops. In addition to that, vegetables are also grown in a small part of the area, which is not indicated separately. Crop water requirements for existing cropping pattern under the study area has evaluate and shown in Table 2. 
The food self-sufficiency is a major thrust in India. Since rice is one of the major components of food, all agricultural practices in and around the area are targeted to achieve sufficient production of rice. In the study area the present cropping pattern and agricultural practices are prevailing as per their socioeconomic requirements, which include selfsufficiency in food., employment and availability of agricultural infrastructure. So in the present study, the self-sufficiency of food through paddy and wheat have been proposed as a major crop in the cropping pattern along with other crops like sugarcane, pulses and oilseeds.

\section{Cost and benefit parameters}

The cost of providing surface water for the irrigation to various crops is worked out based on the total cost (capital, operation and maintenance). Surface water charges are very much less as compared to groundwater. The estimated average unit costs of surface water and ground water are 1101.59 (Rs/ham) and 2527.64 (Rs/ham), respectively. Based on agricultural inputs and produced crops in the study area, net benefits / ha for various crops are given in Table-3. These units cost and net benefits have been used in the optimization model as cost and benefit constraints.

\section{Linear programming model:}

The linear programming technique has been used to formulate the water use optimization model, to arrive the optimal allocation of surface water irrigation to maximize the benefits within the framework of given constraints and designed cropping pattern (Ediwahyunan, 2002). For which an optimization model is formulated, for surface irrigation system under similar water use regimes. Lastly, optimal strategies of surface water resources are identified to maximize the economic values for a given set of parameters. One year planning horizon has been considered, with monthly planning period. In the present study, the LINDO 6.1 package is used to solve the model. This uses the revised simplex method to solve the linear optimization models. The objective function has been formulated for maximizing the net benefits resulting from the cropping activity in the study area. The unit cost of surface irrigation water, cost of cultivation and other parameters have been considered the same for all the months during which the

Table 2. Crop water requirement for existing cropping pattern under the study area

\begin{tabular}{|c|c|c|c|c|c|c|c|}
\hline \multirow{2}{*}{ S. No } & \multirow{2}{*}{ Months } & \multicolumn{5}{|c|}{ Water resources consumption $(\mathrm{mm})$ by crops } & \multirow{2}{*}{ Total (ha-m) } \\
\hline & & Paddy & $\begin{array}{l}\text { Sugar } \\
\text { Cane }\end{array}$ & Maize & Wheat & $\begin{array}{c}\text { Moong } \\
\text { (Pulses) }\end{array}$ & \\
\hline 1 & July & 448 & 57 & & & & 920 \\
\hline 2 & Aug & 191 & 43 & & & & 505 \\
\hline 3 & Sept & 312 & 55 & & & & 234 \\
\hline 4 & Oct & 151 & & & 49 & & 367 \\
\hline 5 & Nov & & & & 80 & & 200 \\
\hline 6 & Dec & & & & 93 & & 80 \\
\hline 7 & Jan & & & & 87 & & 93 \\
\hline 8 & Feb & & & & 74 & & 87 \\
\hline 9 & Mar & & 45 & & 63 & & 74 \\
\hline 10 & April & & 147 & 42 & & 21 & 108 \\
\hline 11 & May & & 480 & 83 & & 243 & 210 \\
\hline 12 & June & 172 & 653 & 30 & & 65 & 806 \\
\hline \multicolumn{2}{|c|}{ Total } & 1274 & 1480 & 155 & 446 & 329 & 3684 \\
\hline
\end{tabular}


Table 3: Net benefits per hectare for various crops

\begin{tabular}{|c|l|c|c|c|c|c|}
\hline S. No. & Crops & $\begin{array}{c}\text { Grain } \\
\text { yield } \\
\text { (Kg/ha) }\end{array}$ & $\begin{array}{c}\text { Unit price } \\
\text { (Rs/Kg) }\end{array}$ & $\begin{array}{c}\text { Total } \\
\text { receipt } \\
\text { (Rs/ha) }\end{array}$ & $\begin{array}{c}\text { Cost of } \\
\text { cultivation } \\
\text { (Rs/ha) }\end{array}$ & $\begin{array}{c}\text { Net benefits } \\
\text { (Rs/ha) }\end{array}$ \\
\hline 1 & Paddy & 5,600 & 13.00 & 72,800 & 22,852 & 49,948 \\
\hline 2 & Sugarcane & 50,000 & 2.80 & $1,40,000$ & 27,200 & $1,12,800$ \\
\hline 3 & Maize & 2900 & 14.00 & 40,600 & 6,300 & 34,300 \\
\hline 4 & Wheat & 4000 & 16.00 & 64,000 & 22,571 & 41,429 \\
\hline 5 & Moongbean & 800 & 30.00 & 24,000 & 7,740 & 16,260 \\
\hline
\end{tabular}

Surface irrigation water is available. The objective function is formulated considering

Maximize net annual benefits

$$
\begin{aligned}
= & \sum_{i=1}^{n z} \sum_{j=1}^{n c} A_{i j} \times\left(Y_{j} \times P_{j}-C C L_{j}\right) \\
& -\sum_{i=1}^{n z} \sum_{k=1}^{12}\left\{C S C_{i}+C S O_{i}\right\} \times S W_{i, k} \\
& -\sum_{i=1}^{n z} \sum_{k=1}^{12} C G T_{i} \times G W_{i, k}
\end{aligned}
$$

benefits and unit costs of providing water, which can be expressed as:

Or

Maximize $\quad Z=\sum_{i=1}^{n z} \sum_{j=1}^{n c} A_{i . j} \times N B_{j}-\sum_{i=1}^{n z} \sum_{k=1}^{12} C S T_{i} \times S W_{i, k}-\sum_{i=1}^{n z} \sum_{k=1}^{12} C G T_{i} \times G W_{i, k}$

Where $i$ is the number of zones of the study area $(\mathrm{i}=1,2,3, \ldots, n z), j$ is the number of crops ( $\mathrm{j}=1,2,3, \ldots, \mathrm{nc}), \mathrm{k}$ is the number of months $(\mathrm{k}=$ $1,2,3, \ldots, 12), A_{i, j}$ is the area under $j^{\text {th }}$ crop in the $i^{\text {th }}$ zone (ha), $Y_{j}$ is the yield of $j^{\text {th }}$ crop (kg/ha), $P_{j}$ is the price of $j^{\text {th }}$ crop (Rs/kg), $\mathrm{CCL}_{\mathrm{j}}$ is the total cost of cultivation for $j^{\text {th }}$ crop excluding the cost of water, $N b_{j}$ is the net benefits for $j^{\text {th }}$ crop, $C S C_{i}$ is the unit capital cost of the surface water for $i^{\text {th }}$ zone (Rs/ha-m), $\mathrm{CSO}_{i}$ is the unit operation and maintenance cost of surface water for $i^{\text {th }}$ zone (Rs/ha-m), $C S T_{1}$ is the total unit cost of surface water for $i_{t h}$ zone (Rs/ha-m), $S W_{i, k}$ is the surface water allocation for $i^{\text {th }}$ zone during $k^{\text {th }}$ time interval (ha-m), $C G T_{1}$ is the total unit cost of groundwater for $i^{\text {th }}$ zone(Rs/ha-m), $G W_{i, k}$ is the groundwater allocation for $i^{\text {th }}$ zone during $k^{\text {th }}$ time period(ha-m).

The objective function (Eq. 1) is to be maximized subject to the variety of constraints:

Water requirement constraints: The total monthly water requirement for all the crops in each zone shall be met by surface and groundwater allocations. In the present investigation water requirement has been considered at the canal outlet. Therefore, constraints for water requirement for the crops can be written as:

$$
\sum_{j=1}^{n c} W R_{j, k} \times A_{i, j}=\sum_{i=1}^{n z} S W_{i, k}+G W_{i, k} \quad \forall k
$$


Where $W R_{j, k}$ is the water requirement of $\mathrm{j}^{\text {th }}$ crop for $\mathrm{k}^{\text {th }}$ time period(m), $A_{i, j}$ is the area of $j^{\text {th }}$ crop for $j^{\text {th }}$ zone (ha).

Area availability constraints: For each zone, culturable command area (CCA) has been worked out. The total area under all the crops cannot exceed the CCA at that particular zone

$$
\begin{array}{ll}
\sum_{j=1}^{n c} \lambda_{j, k w} \times A_{i, j} \leq C C A_{i} & \forall i \\
\sum_{j=1}^{n c} \lambda_{j, k d 1} \times A_{i, j} \leq C C A_{i} & \forall i \\
\sum_{j=1}^{n c} \lambda_{j, k d 1} \times A_{i, j} \leq C C A_{i} & \forall i
\end{array}
$$

for all the seasons. A land use coefficient, which is the ratio of land under particular crop to total culturable command area, is used for this constraint. Since there are three cropping season, i.e. Kharif season, Rabi season and Zaid season, for each season one constraint is sufficient and which can be written as:

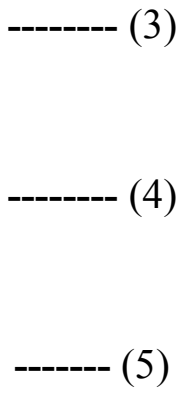

Where $\lambda_{j, k w}$ is the land use coefficient for $\mathrm{j}^{\text {th }}$ crop in kwth time, $\lambda_{j, k d 1}$ is the land use coefficient for $j^{\text {th }}$ crop in kd1th time, $\lambda_{j, k d 2}$ is the land use coefficient for $j^{\text {th }}$ crop in $\mathrm{kd} 2^{\text {th }}$ time, $k w$ is a month of Kharif season, $k d_{l}$ is a month of Rabi season, $k d_{2}$ is a month of Zaid season, $C C A_{i}$ is the culturable command area for $i^{\text {th }}$ zone (ha).

$$
\sum_{i=1}^{n z} \sum_{k=1}^{12} \frac{S W_{i, k}}{\left(E S_{d m i} \times E S_{c i}\right.} \leq \sum_{k=1}^{12} S W A_{k} \quad \forall k
$$

where $S W_{i, k}$ is the surface water allocation for $i^{\text {th }}$ zone during $k^{\text {th }}$ time interval (ha m), $E S_{d m i}$ is the efficiency of the surface water system for distributaries and minors for $i^{\text {th }}$ zone, $E S_{c i}$ is the conveyance efficiency of canal for $i^{\text {th }}$ zone, $S W A_{k}$ is the surface water available at the head of canal (ha m) for $k^{\text {th }}$ time interval (ha m).
Crop area constraints: Depending upon socioeconomic needs of the area these constraints are applied. These constraints have been imposing on each individual crop such that:

$$
A_{i j}=P_{i j} \times C C A_{i}
$$

Where $p_{i j}$ is the percentage of $j_{t h}$ crop in $i_{t h}$ zone with respect to CCA of $i_{t h}$ zone, i.e., ratio of area under $j_{t h}$ crop in $i_{t h}$ zone and CCA of $i_{t h}$ zone. 


\section{Results and Discussion}

The model has been used to investigate the different integrated water use policy options. To understand the present scenario, the model has been run for existing cropping pattern with the present condition and then various cases has been investigated for proposed cropping patterns with different alternatives (three scenarios) of surface and groundwater (when no surface water is available through canal) utilization.

The first simulation is carried out considering the present cropping pattern and irrigation practices in which groundwater use is not in practice. The groundwater variable is kept as zero during the simulation and a net benefit of 45061.42 Million Rupees (M Rs) has been obtained using 4038.44 ha-m surface supplies. Areas under crops is Kharif, Rabi and Zaid seasons have been obtained as 45\% (2250 ha), $30 \%$ (1965ha) and 25\% (1230ha) of the CCA (4917ha), respectively. Model results for this case are presented in Fig. 1.

Different scenarios of the proposed cropping pattern under the conjunctive use scheme have been formulated, considering percentage of the area under the different crops in the different seasons to arrive at maximum value of the objective function. Proportion of the area (\% of CCA) under the different crops in Kharif , Rabi and Zaid season has been kept fixed in all the scenarios. In the Kharif season, $70 \%$ area is proposed under paddy and $10 \%$ area under each other crops. In the Rabi season, $40 \%$ area is considered under wheat and $20 \%$ area under each other crops. In Zaid season, 30\% area is considerd under urd-mung and $10 \%$ ara under other crops. Three cases have been formulated by considering different percentage of area under the different crops in various seasons.

In Case-1, paddy and sugarcane, each has been proposed on $27.5 \%$ area and wheat, pulses each on $25 \%$ of the area. A net benefit of 99480.54 M Rs. has been obtained along with
4981 ha $m$ utilization of surface water for irrigation. Net benefit is about $200 \%$ more in this case as compared to the present condition. Allocation plan of the surface and groundwater (at the time of no canal water arability), for this case is presented in Fig. 2.

In Case -II, a net benefit of $99514.55 \mathrm{M}$ Rs has been obtained using 4981 and 3156.38 ha $\mathrm{m}$ of surface and groundwater. Model results for this case are given in Fig.3. Increase in net benefit from the previous case is due to reduction in use of the groundwater, which is costlier than the surface supplies. Overall water requirement is also reduced by 71.30 ha $\mathrm{m}$, which is due to reduction in crop area under the paddy ( $25 \%$ of CCA), whose water requirement is more than that of sugarcane $30 \%$ of CCA).

In Case - III, the area under paddy and sugarcane has been changed to $30 \%$ and $25 \%$ of the area, respectively, as compared to the previous case. Net benefit of $99466.96 \mathrm{M}$ Rs. has been obtained using 4981 ha $\mathrm{m}$ surface water and 3307.29 ha $\mathrm{m}$ groundwater. Groundwater utilization has been slightly increased, which is attributed to reduction in benefit as compared to case I and II. As shown in figure-4.

This study is proposed to present the benefits of irrigation water, as compared to present practices for an area, where it is not being used till now. The Sharda-sahayak irrigation project has been implemented considering only surface water supplies for irrigation. Presently due to the limited availability of surface water, only $45 \%, 40 \%$ and $30 \%$ of the CCA is under irrigation in Kharif, Rabi and Zaid seasons, respectively, since groundwater is not utilized in a planned way. But using the surface and groundwater conjunctively, reliability of the irrigation can be increased which reduces the losses due to uncertainty in rainfall and insufficient surface supplies. The economic value of the present cropping pattern has been evaluated considering 
only surface supplies, as presently groundwater is not in use.

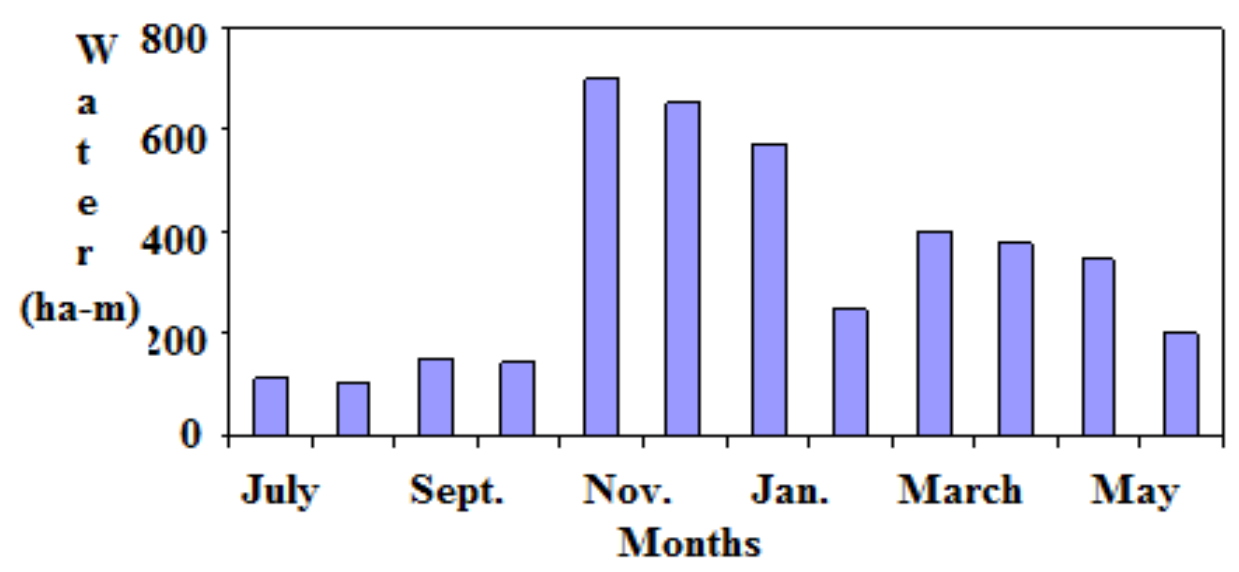

Fig. 1: Optimum water allocation under existing cropping pattern

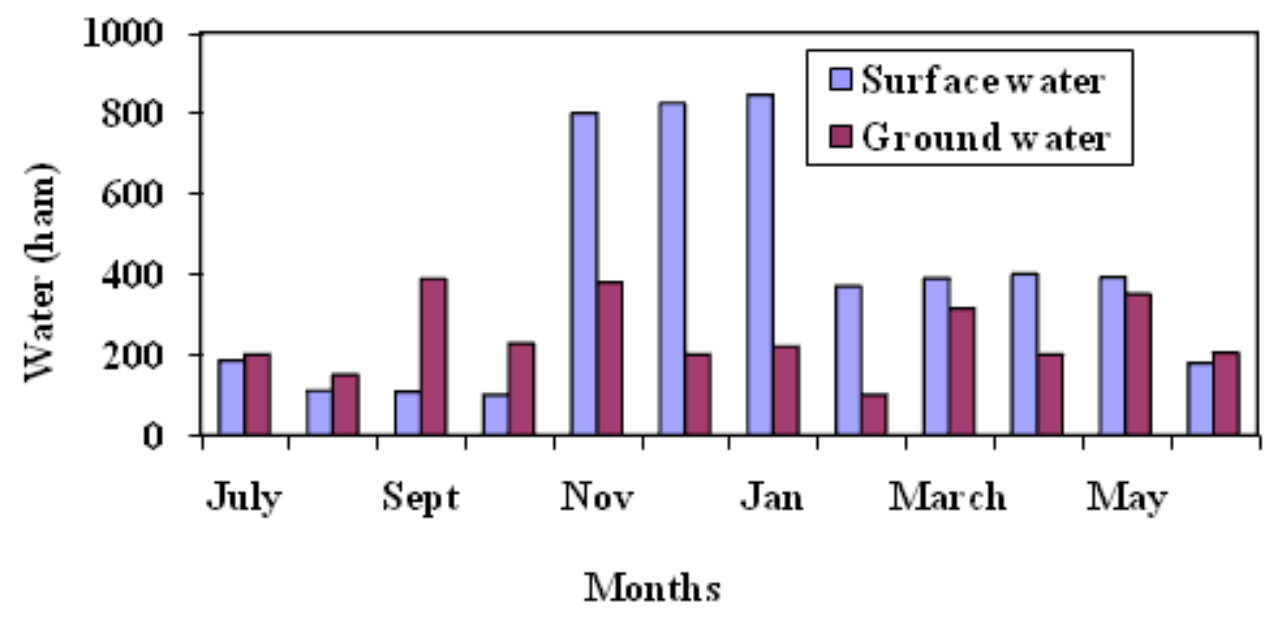

Fig. 2: Optimal allocation of surface and ground water for the proposed cropping pattern for case 1

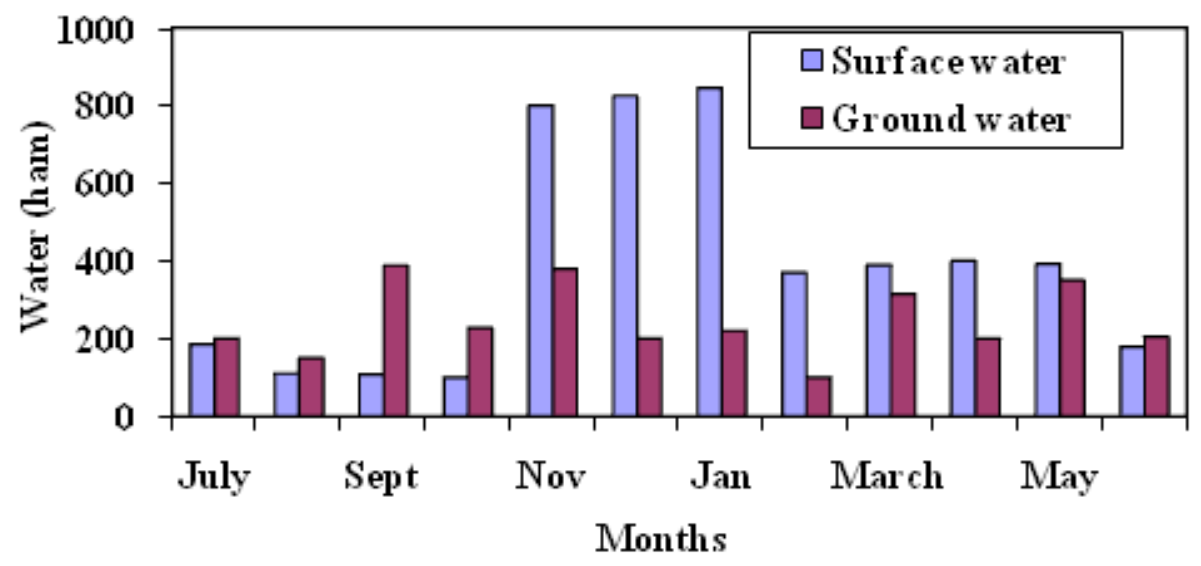

Fig. 3: Optimal allocation of surface and ground water for the proposed cropping pattern for case 2 


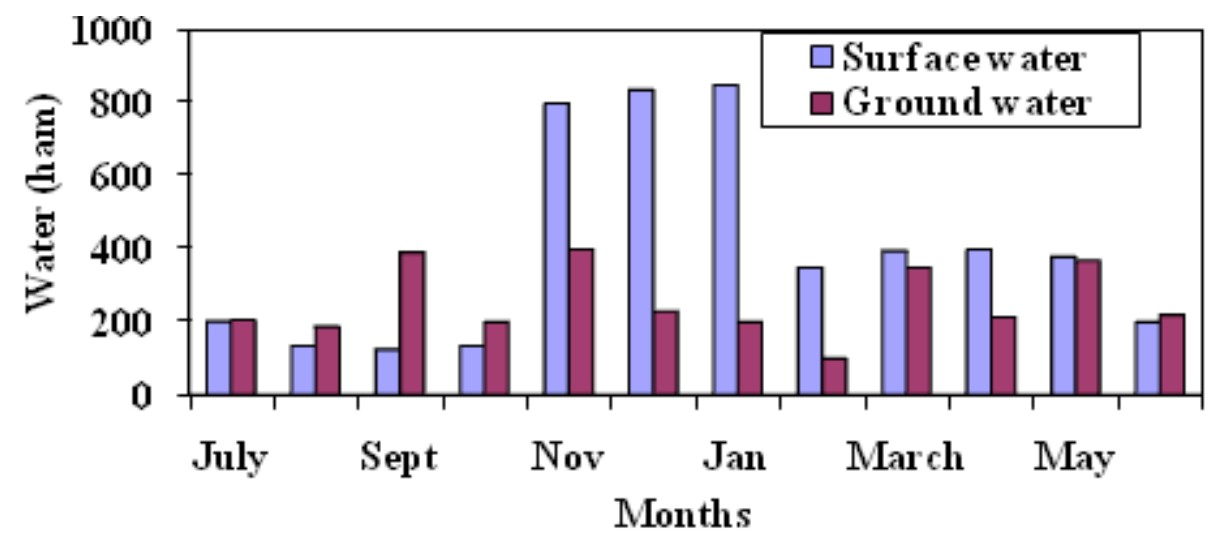

Fig. 4: Optimal allocation of surface and ground water for the prop osed cropping pattern for case 3

Therefore, the net benefit from the proposed water use system is almost double from 45061.42 to $101115.30 \mathrm{M}$ Rs. It is also possible to extend the irrigation facilities to the whole command area as compared to present condition. Using a linear programming-based optimization model, scope of surface water use in a canal command of the India has been investigated by experts and findings are nearly similar in the study. The results indicate that surface water use options are feasible and can be implemented.

\section{Conclusion}

In the present study limited cases in the variation of crop areas in various seasons has been explored for reaching to maximum benefit to the farmers of the study area. The results indicate that surface irrigation water use options are feasible and can be easily implemented in the study area under planned way.

\section{References}

1. Aron, G. (1969). Optimization of conjunctively managed surface and groundwater resources by dynamic programming; Water Resources Centre
Contribution, University of California, Vol. 129: 158.

2. Aron, G. and Scott, V.H. (1971). Dynamic programming for conjunctive use. Journal of Hydraulics Division, ASCE 97(5), 705721.

3. Azaiez, M.N., and Hariga,M, (2001) A single-period model for conjunctive use of groundwater and surface water under severe overdrafts and water deficit. European Journal of Operation Research 133(3): 653-666.

4. Ediwahyunan (2002). Conjunctive use planning for sapon irrigation project of Indonasia. Unpublished M.Tech. Dissertation, Department of Water Resources Development and Management, Indian Institute of Technology, Roorkee, India.

5. Haimes, Y.Y. and Dreizen, Y.C. (1977). Management of groundwater and surface water via decomposition. Water Resources Research, The American Geophysical Union, 13(1): 69-77.

6. Illangasekare, T.H., Morel-Seytoux, H.J. and Edward, J.K. (1984). Application of a physically based distributed parameter model for arid zone surface-groundwater 
management. Journal of Hydrology, 74: 233-257.

7. Karamouz, M., Kerachian, R. and Zahraie, B. (2004). Monthly water resources and irrigation planning: Case study of conjunctive use of surface and groundwater resources. Journal of Irrigation and Drainage Engineering, ASCE 130(5): 93-98.

8. Latif, M. and James, L.D. (1991). Conjunctive use to control water logging and salinization. Journal of Water Resource Planning and Management, ASCE 117(6): 611-628.

9. Matsukawa, J., Finney, B.A. and Willis, R. (1992). Conjunctive use planning in mad river basin, California. Journal of Water Resources Planning and Management, ASCE 118(2): 115-132.

10. O'Mara, G.T. and Duloy, J.H. (1984). Modeling efficient water allocation in a conjunctive use regime, Te Indus basin, Pakistan. Water resource research, The American Geophysical Union, 20(11): 1489-1498.

11. Onta, P.R., Gupta, A.D. and Harboe, R. (1991). Multistep planning model for conjunctive use of surface and groundwater resources. Journal of Water Resources Planning and Management, ASCE 117(6): 662-678.
12. Rao, S.V.N., Murthy, S.B., Thandaveswara, B.S. and Mishra, G.C. (2004). Conjunctive use of surface and groundwater for coastal and deltic system. Journal of Water Resource Planning and Management, ASCE 130(3): 255-266.

13. Reichard, E.G. (1995). Groundwater surface water management with stochastic surface water supplies: A simulation optimization approach. Water Resource Research, The American Geophysical Union, 31(11): 2845-2865.

14. Syaukt, S. and Fox, G.C. (2004). Conjunctive surface and groundwater management in the Jakarta region of Indonasia. Journal of the American Water Resource Association, Pro Quest Science Journal, 40(1): 241-250.

15. Vedula, S., Mujumdar, P.P. and Sekhar, G.C. (2005). Conjunctive use modeling for multi crop irrigation. Agricultural Water Management, 73: 193-221.

16. Watkins, J.D.W. and Mckinney, D.C. (1998). Decomposition methods for water resources optimization models with fixed costs. Advances in Water Resources 21, 283-295.

17. Willis, R., Finney, B.A. and Zang, D. (1989) Water resources management in North China Plain. Journal of Water Resource Planning and Management, ASCE 115(5): 598-615. 